\title{
Climate Change and Community Perceptions in the Khudi Watershed, Lamjung, Nepal
}

\section{Aseem Raj Sharma}

\begin{abstract}
Climate change and people's perception on such changes are analysed for the Khudi Watershed in Western Nepal. Climate change trends in the western hilly region of Nepal were investigated focusing on two major climatic indicators: surface air temperature and rainfall. Further, community's perceptions on climate change impacts were analysed. We found considerable warming in the study area with a mean temperature increase of $0.18^{\circ} \mathrm{C}$ decade-1. Annual rainfall is varying with prolonged dry periods. During monsoon season short but intense rainfall events were observed. Local denizens have also experienced these changes and think that weather related changes are affecting their livelihood practices with increased weather related disasters, less agricultural yield, and imbalances in socio-economic behaviour.
\end{abstract}

Keywords: Climate change, Khudi watershed, Trends, Impacts, Community, People's perceptions, Nepal

\section{Introduction}

$T^{t}$ is generally accepted that the earth is warming at 1 a faster rate in recent decades than any time during the past thousands of years. The $5^{\text {th }}$ assessment report of the Intergovernmental Panel on Climate Change (IPCC, 2013) states that "warming of the climate system is unequivocal and since the 1950s, many of the observed changes are unprecedented over decades to millennia, the atmosphere and ocean have warmed". Further, IPCC AR5 report shows that the global air temperature trend and decadal averages from 1850 to 2010 is increasing (IPCC, 2013). Globally-averaged land and ocean combined temperatures show a warming trend of 0.72 [0.49 to 0.89$]^{\circ} \mathrm{C}$ over the period 1951-2012 (Stocker et al., 2013). According to the IPCC (2007), eleven of the last twelve years (1995-2006) rank among the twelve warmest years on record for global surface temperatures (since 1850). These changed climate scenarios are challenges for long term sustainability of both the developing and developed worlds.

Together, increasing temperatures, varying rainfall, frequent drought and flooding, and high rates of snow melt are threatening the sustainable continuity of the living planet. Recently, human activities have been identified as likely contributors to global as well as regional climate change (IPCC, 2013). Temperature is a good indicator of climate change. Rainfall may be of equal or greater importance indicator for global climate change because of the impacts associated with water shortages and quality (Shrestha et al, 1999). Increases in greenhouse gases (GHGs) emissions, particularly from anthropogenic sources, have been causing the positive radiative forcing and therefore, surface warming globally (IPCC, 2013). Although these changes are global, the impacts of climate change are localized to regional to global. Therefore, it is important to investigate how climate variation and change are occurring at local level and what are the experiences and perceptions of the local communities towards such changes.

Advanced knowledge on climate change and their relation with communities can help improve management of local resources and assist to formulate adaptation strategies in the face of climate change, thereby lessening the potential negative impacts to natural and socio-economic dynamics of local communities. For communities, adaptation is a process of social learning, developed through their perception and the policy implemented. The local communities are more vulnerable to climate change because of their direct and more exposer thus sensitive indicator of climate change impacts at community level (Adger et al, 2003; Bharati et al, 2012; Gurung et al, 2013; and Hua, 2009)

It is very important to understand how community is perceiving global climate change, what are their impacts in order to develop proper adaptation solutions to minimize the risk associated with such changes. Therefore, the objectives of this paper are to: (1) explore the annual and seasonal trends of the air temperature and rainfall in the Khudi Watershed of Lamjung, Nepal; and (2) compare measured climate change with peoples' perception.

The remainder of this paper is structured as follows:

\section{Study Area}

This study was carried out in the Khudi Watershed of Lamjung district in Western Nepal. It is located at latitude $28^{\circ} 03^{\prime}-28^{\circ} 30^{\prime}$ North, $84^{\circ} 11^{\prime}-84^{\circ} 38^{\prime}$ East with elevation ranging from $823 \mathrm{~m}$ to $3000 \mathrm{~m}$ (Figure 1 ). The Khudi Watershed is a subsystem of Marsyangdi watershed and is in oval shape.

The study area is a typical hilly region with landscape of rugged topography of Northern Mahabharata range to Himalaya belt with Manaslu and Lamjung Himal in the north. This region lies with geological extension from middle hill to northern Himalaya and is one of biodiversity rich fragile region of Nepal. Furthermore, the study area lies within the Annupuran Conservation Area. Climate of the area varies from sub-temperate at lower altitude to subalpine at higher altitudes with average annual rainfall $3345.755 \mathrm{~mm}$ and average maximum air temperature $27.17^{\circ} \mathrm{C}$ and minimum air temperature $15.50^{\circ} \mathrm{C}$. More than $80 \%$ of total rain fall occurs between June to September i.e. during monsoon period.

The watershed encompasses different wards of 
three Village Development Committees (VDCs): Khudi, Simpani and Ghanpokhara. Total population of the three VDCs of the watershed area is 10,447 (4,890 male and 5,557 female) and total households are 2,099 with average population density of 133.54 (CBS, 2006). The watershed area is dominated by Indo-Aryans such as Brahmin, Chhetri followed by Mongolian origin Gurungs. Agriculture is major occupation followed by foreign employment as Lahure mainly from Gurung community. Almost all the household of Gurung has at least one Indian or British army or ex-army pensioner. Livelihood of most of the people is based on the integrated system of farming, forests and livestock as in other hilly areas of Nepal. But young generation is being more engage in foreign employment, tourism and business.

This area was selected as study site as western region of Nepal is considered as one of the highly temperature increasing region of country and because of the availability of hydrological and meteorological data since 1981.

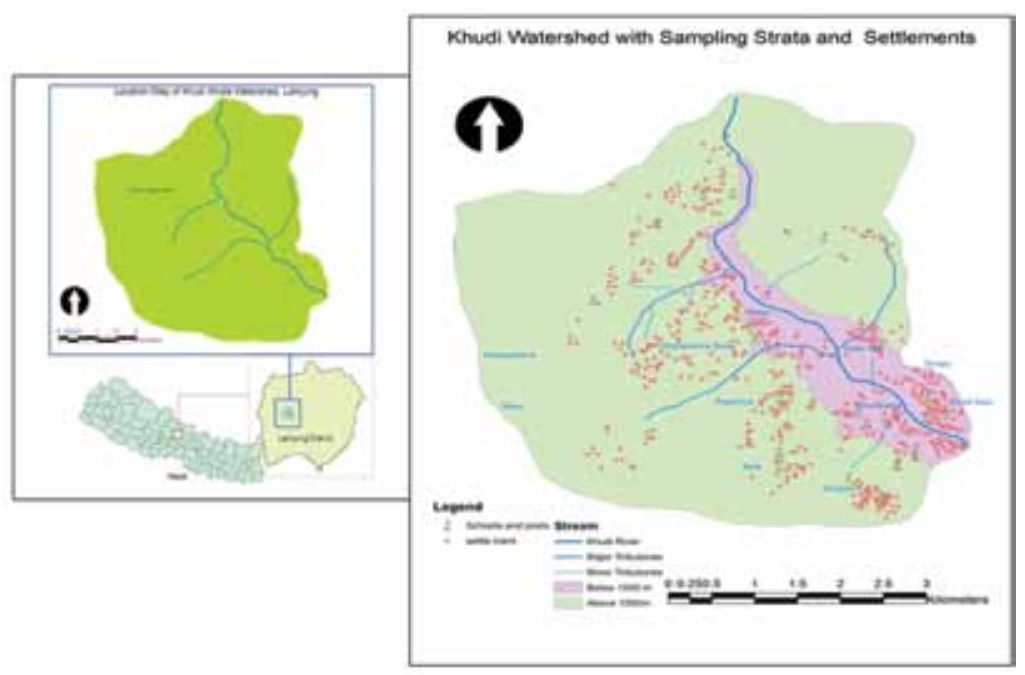

Figure 1: Location of study area Khudi Watershed and sampling strata in the watershed.

\section{Methodology}

\section{Approach}

Two steps research approach was adopted for this study. First, the climate change of the region was assessed conducting analysis of measured long term temperature and rainfall changes. Second, the socioeconomic status and people perception was surveyed. In this approach, we combine scientific data along with people's responses and experience sharing to assess and better understand the nature of vulnerability of communities to climate change.

\section{Data}

There is only one weather station within the Khudi watershed run by Department of Hydrology and Meteorology (DHM), Government of Nepal. The stations has monthly records of daily rainfall since 1975 while temperature records are only from 1987 till 2006 when data were collected for this analysis. The monthly air temperature (minimum and maximum) and rainfall data of Khudi station were collected and

\section{Results} trends. analysed after quality control.

The community perception data were obtained through household survey, Focus Group Discussions (FGDs) and Key Informant Interviews (KIIs).

\section{Methods \\ Climate Trends}

The trends of the temperature and rainfall are calculated following least square linear regression model (Wilks, 2011).

Let $\mathrm{x}_{1}, \mathrm{x}_{2}, \mathrm{x}_{3}, \ldots \ldots \mathrm{x}_{\mathrm{n}}$ represent data points where represents the data point at time $\mathrm{j}$. Then the linear equation of the data series is represented as

$$
y=m x+c
$$

where $\mathrm{x}$ represent the data series $\mathrm{x}_{1}$ for time $i=1$ to $n$ and $m$ gives magnitude of slope of the trend line. Positive value of $m$ shows the increasing trend while negative value gives the decreasing trend.

\section{Community Perception}

To collect people's perceptions on climate change and its impacts, conducted household surveys, held multiple FGDs and KIIs. We divided the population (i.e., number of households) of the watershed into two strata by altitude, considering that the altitudinal variation creates heterogeneity in the livelihoods of the local people, especially on the factors related to climatic variation (Weiss \& Hassett, 1982). Therefore, the entire watershed was stratified into two regions based on elevation as region below $1000 \mathrm{~m}$ and above $1000 \mathrm{~m}$ (Figure 1). For each region, three FGDs were conducted. Further, KIIs were conducted in a way that at least one is selected from each of three VDCs. Ninety households were chosen randomly from the numbered list of all the household of the study area.

Temperature Trend

The climate change in the Khudi region was measured through the analysis of mean annual minimum and maximum air temperatures and rainfall

Recorded temperature of Khudi Watershed from 1987 to 2006 shows the increasing trend of both minimum and maximum air temperatures. Maximum air temperature is increasing at the rate of $0.26{ }^{\circ} \mathrm{C}$ decade $^{-1}$ while minimum air temperature is increasing at the rate of $0.12^{\circ} \mathrm{C}$ decade $^{-1}$ (Figure 2).

These increases are consistent with many of the regional temperature trend analysis (Shrestha et al, 1999; Baidya et al, 2008). Therefore, the Khudi area is warming each year and expected to warm in years to come. Seasonal air temperature trend analysis shows that winter air temperatures increases alone 
are alarming. The maximum and minimum air temperatures increased over the period of 1987-2006 are at the rate of $0.76^{\circ} \mathrm{C}$ decade $^{-1}$ and $0.17^{\circ} \mathrm{C}$ decade $^{-1}$ respectively. This indicates that the western mountain hill of Nepal is warming rapidly, and experiencing warmer winters and thus more rapid melting snow in high mountain peaks. Further, this temperature increase support the argument made by local people that the snow cover area of upper part of Khudi Watershed is decreasing each year. As temperature is expected to increase in years to come, it is almost certain that there would be increased rate of melting in coming years. This may affect the water availability of the region that will directly influence the agriculture dependent communities' livelihood.

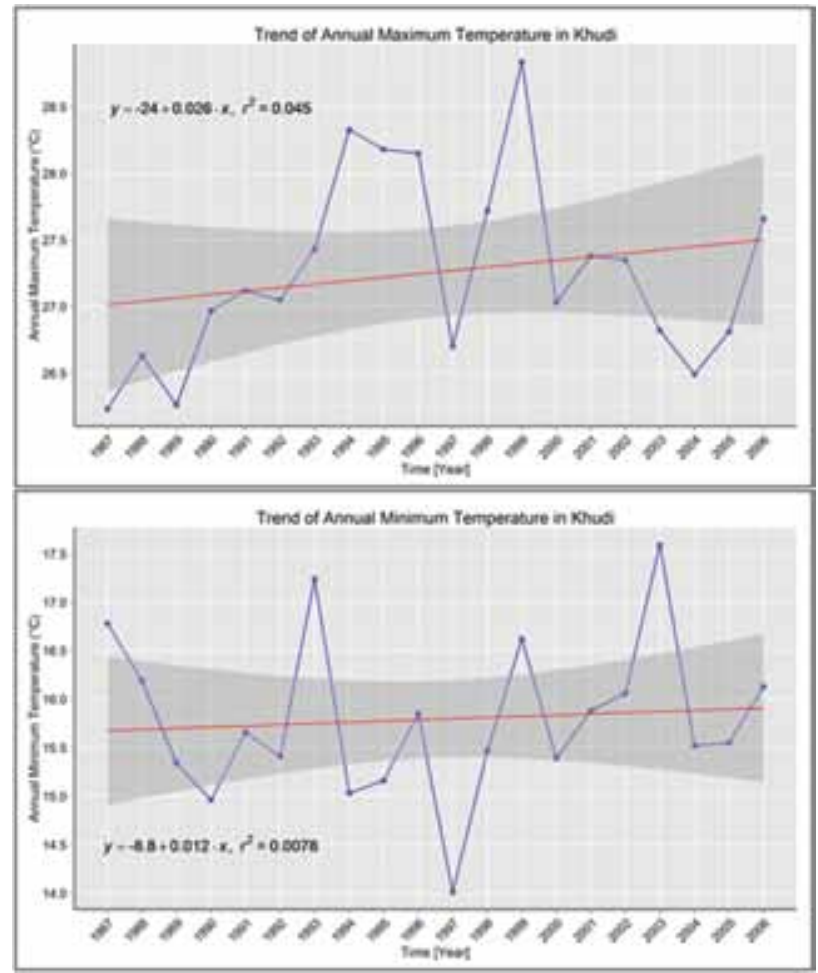

Figure 2: Figures showing the linear trends of maximum (above) and minimum (below) temperature trend in the Khudi watershed. The Red line is the trend line, the shaded area represents the region of confidence while the equation shows the direction and magnitude of the trend.

Figures 3 and 4 show the seasonal minimum and maximum air temperature trends in the Khudi Watershed over the period of 1987 to 2006. Premonsoon maximum air temperatures found to be increasing at the rate of $0.16^{\circ} \mathrm{C}$ decade $^{-1}$ while minimum air temperatures found to be increasing at the rate of $0.39^{\circ} \mathrm{C}$ decade $^{-1}$. These findings are consistent with reported national averages. In addition, the maximum temperature during monsoon do not shows specific trend while that of minimum temperature shows a very slow increase $\left(0.02{ }^{\circ} \mathrm{C}\right.$ decade $\left.^{-1}\right)$. The post monsoon minimum temperature is also increasing significantly $\left(0.44^{\circ} \mathrm{C}\right.$ decade $\left.^{-1}\right)$ but that of maximum temperature is increasing very slowly $\left(0.01^{\circ} \mathrm{C}\right.$ decade $\left.^{-1}\right)$. This seasonal variation in the temperature trend is influenced by many factors such as cloud concentration in sky which is generally high during monsoon, the continentally etc.
Increases in temperature, both on annual and seasonal, has great influence on the community's livelihood of the Khudi Watershed which is dominantly agriculture dependent. It disturbs cropping patterns and yield; it influences community practices, and forces locals to look for new resources such as water source or even switch from traditional agricultural practices.

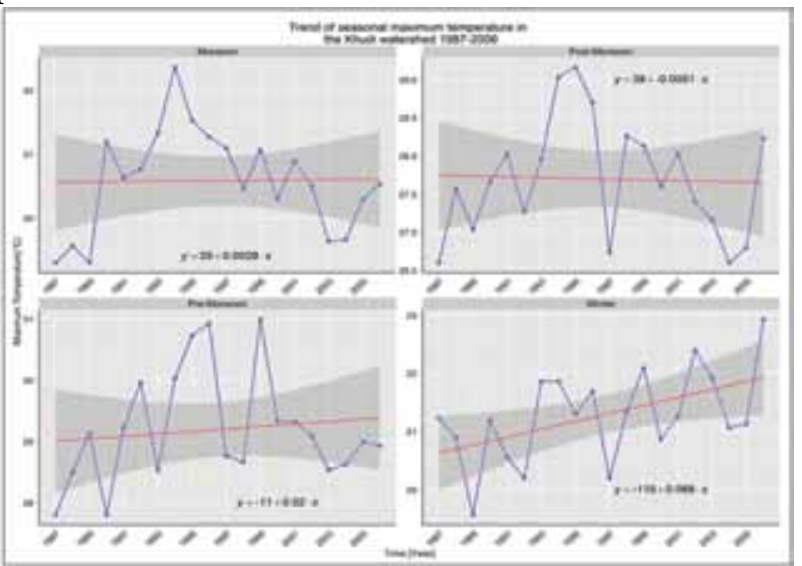

Figure 3: Trend of Seasonal maximum temperature at the Khudi Watershed (1987-2006).

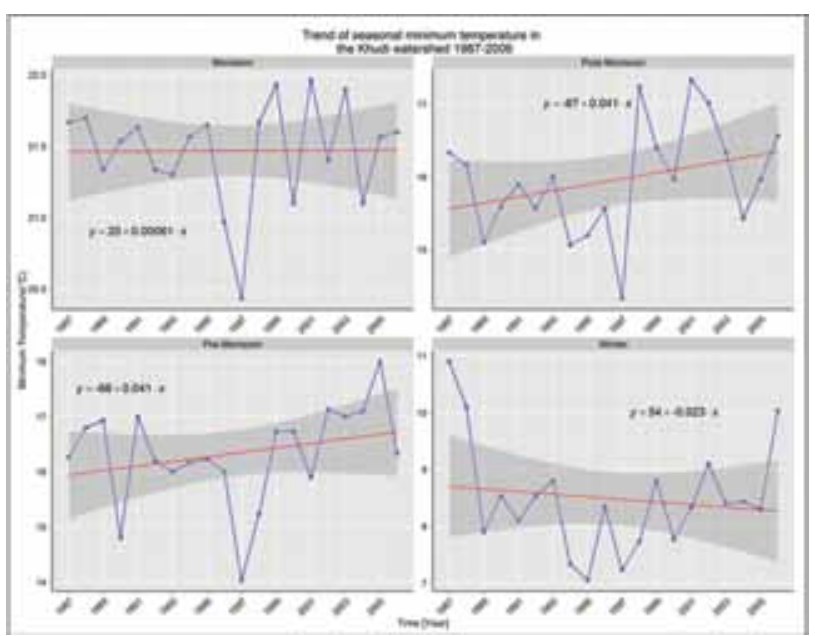

Figure 4: Trend of Seasonal minimum temperature at the Khudi Watershed.

\section{Rainfall Trend}

We analysed thirty years of rainfall data from the Khudi meteorological station. Annual total rainfall of the watershed is $3346 \mathrm{~mm}$. The four months of monsoon, from June to September, contribute $81 \%$ of the total annual rainfall in the area. This is the most sensitive period for weather-related disasters, especially flooding and landslides.

Figure 5 shows the trend of annual total rainfall for period of 1975 to 2006. There is insignificant increasing trend $\left(10 \mathrm{~mm}\right.$ year $\left.^{-1}\right)$. Higher rate of increasing air temperature and lower rainfall results in greater evapotranspiration, therefore less water available for ground recharge, springs and rivers of the area.

Figure 6 shows that total monthly rainfall trends over the two wettest months show a slight increase in rainfall $\left(1.90 \mathrm{~mm} \mathrm{yr}^{-1}\right.$ in August and $1.91 \mathrm{~mm} \mathrm{yr}^{-1}$ in 
July) during 1975 to 2006. However, the dry months rainfall trend is decreasing (November $0.58 \mathrm{mmyr}-1$ and December $0.55 \mathrm{~mm} \mathrm{yr}^{-1}$ ).

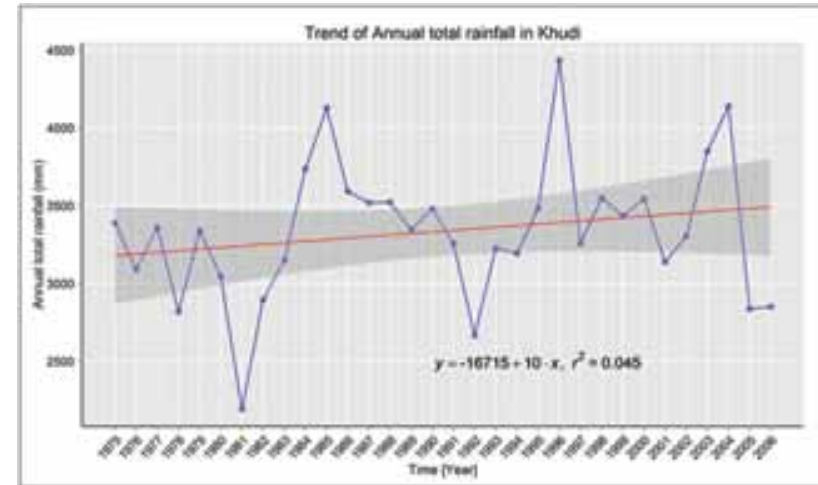

Figure 5: Annual Total Rainfall Trend in the Khudi Watershed, (1975 to 2006).

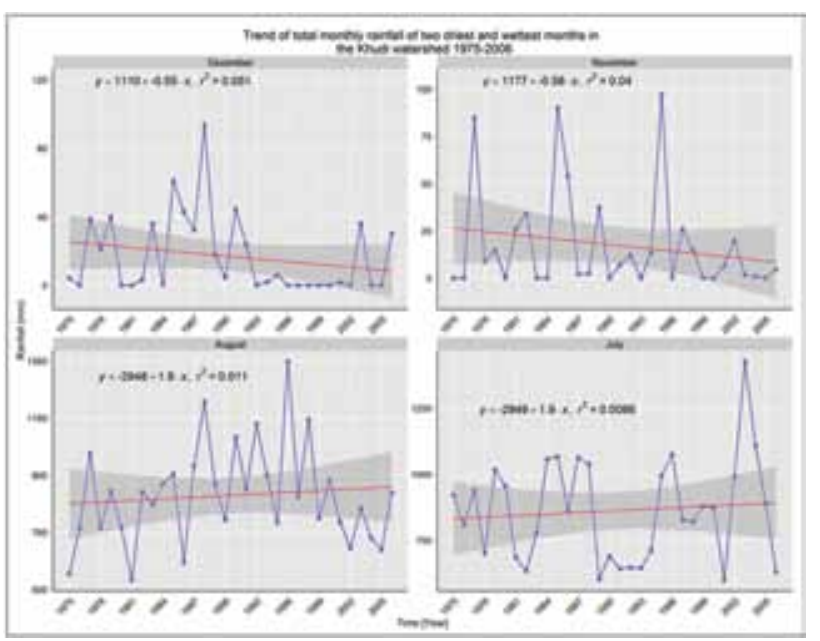

Figure 6: The trend of two driest [November and December] and wettest [July and August] months' total monthly rainfall in the Khudi Watershed.

We can argue that the number of intense rainfall events occurrence is increasing because total rainfalls as well as rainfall of the two wettest months are increasing but dry months are decreasing. Furthermore, the high fluctuation in the rainfall patterns shows an increasing uncertainty in rainfall. It has great influence on agricultural practice and total production yield which directly influences community's socio-economic state.

In summary, seasonal rainfall analysis shows increases in pre-monsoon and monsoon rainfall, but decreases in winter and post-monsoon rainfall. The heavier rainfall in the summer months will increase the frequency of number of water induced disasters such as river flooding in lower elevation region and landslides in higher elevational region. In addition, the decreased rainfall during dry months of winter will affect community water demand for household consumption as well as agriculture. In long run, this may cause community conflict due to limited water resources available in the region as well as food shortage because of reduced production in winter crops such as wheat and potatoes.

\section{People's Perception and Impacts}

Total of 90 households in two strata above and below $1,000 \mathrm{~m}$ were surveyed to understand the community perception on the changing climate and its impact in the community.

Majority of the residents of the study area have experienced that the temperature has increased in recent years (Figure 7).

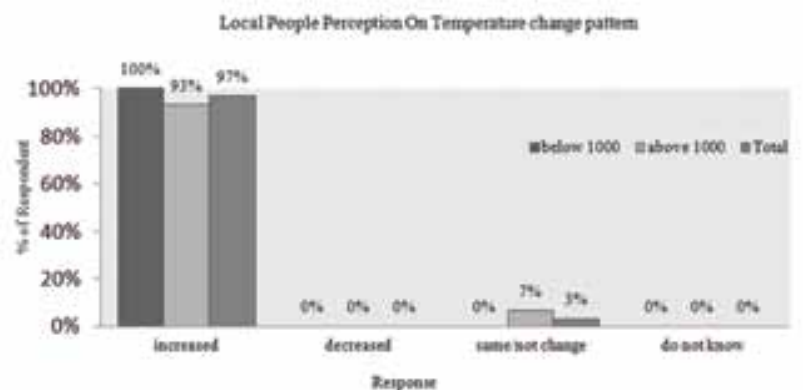

Figure 7: Local people perception on temperature change pattern.

All the respondent below $1000 \mathrm{~m}$ elevation felt increase in temperature while only $97 \%$ of above 1000 $\mathrm{m}$ elevation respondents believe so. Generally, higher elevation regions are colder than the lower one and this influence people's experience.

In addition to regular temperature change pattern we asked people about their experience on different temperature indices changes such as number of hotter or colder days. Fifty three percent of upper zone respondent felt less cold winter days and $73 \%$ felt extreme hot summer days in the region. In case of lower zone, $94 \%$ respondent felt extreme hot summer days but only $21 \%$ said they have felt less cold winter days (Figure 8). These figures show the significant differences in experiencing the changing climate at different elevations.

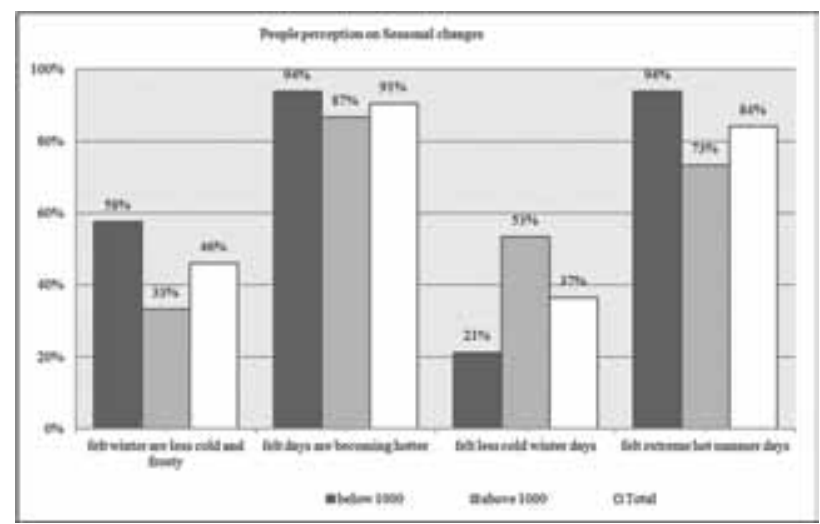

Figure 8: People's experiences on seasonal temperature changes in the Khudi Watershed.

When asked about the patterns of rainfall in their region, $73 \%$ of upper zone and $55 \%$ of lower zone residents said that rainfall amounts had decreased in recent years (Figure 9). Furthermore, about 10\% of total respondent has not perceived any changes in the rainfall while about $27 \%$ of total respondent says that the increase in the rainfall in Khudi. This kind of small inconsistencies may be because of how the 
residents experience their need of water. For example, one farmer may notice the rainfall change during crop planting time, a local hotel business person will notice heavy rainfall when there are no guest because of flooding. Farmers have clear experiences on the changes in the rainfall amount. They have experienced less rainfall especially at the time when they have to plant their crops. They believe that this is a cause behind lower crop yield.

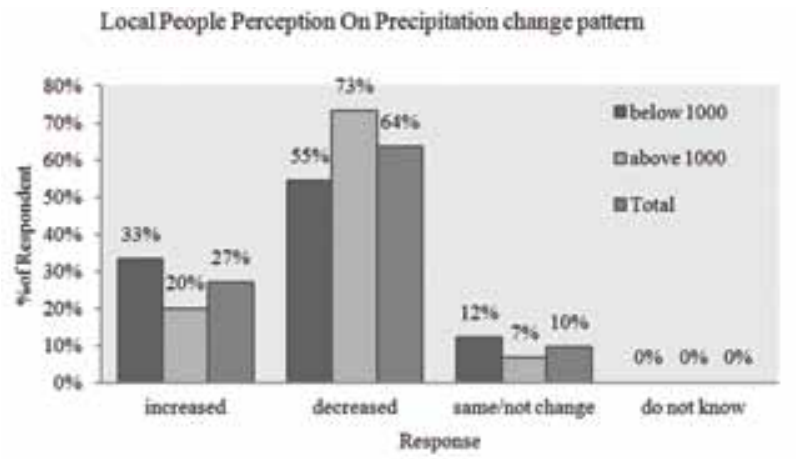

Figure 9: Local People perception channge pattern

Further to people's perception on temperature and rainfall change in the region and its impact, Focus Group Discussions (FGDs) were conducted. According to elderly residents who were the responder at FGDs, winters are less chilly, while rainfall has been decreasing and summer days are hotter in recent decades. The community perceptions clearly indicate a significant change in the local climatic pattern, particularly with respect to temperature, rainfall and seasonal temperature experiences. The community feels that the region is not only getting warmer but it is also affecting their livelihood. On average, respondents held 1.67 ropani of rain fed Khet (Farm land for rice production) ( 1 ha $=19.66$ ropani) and they believed that the changing rainfall would affect their productivity.

In addition to rainfall and air temperature changes, community has experience many climatic changes in the study area in recent decades which is discussed below. This perception is obtained from the FGDs and KIIs conducted in the study area. The community has experienced delay in monsoon start timing. Furthermore, they have experienced that when the monsoon starts, it is very intense. This may cause frequent flash floods in an oval shape watershed like Khudi. People are aware and worried that the low rainfall within the area and less snowfall in upper parts may decreases water level in the river and makes the area drier. They believe that this has direct consequence on agricultural production of the region but they do not know the solution. In addition, the communities has experienced increase in the number of natural disasters such as landslide and heavy flooding events. Most of the community felt that the flooding directly affects their Khet and cost a lot each year. Further, they have experienced on increased frequency of prolonged drought period. This indicates that the community is affected by too much water during monsoon and too little water during other times of the year. This affects water resources, agriculture, biodiversity and the livelihood of the society in general. For example, people are leaving for jobs outside community or abroad.

\section{Concluding Summary}

The measured air temperature and rainfall show changing climate over the Khudi Watershed. Both annual minimum and maximum air temperatures are increased by $0.52{ }^{\circ} \mathrm{C}$ and $0.24{ }^{\circ} \mathrm{C}$ during 20 years period from 1987 to 2006. Air temperature trends are positive, therefore the region is warming and expected to warm during years to come. Maximum air temperature is increased during all the seasons except post monsoon while minimum air temperature is also increased during all seasons except winter. The annual total rainfall was increased by $320 \mathrm{~mm}$ during last three decades from 1975 to 2006. Driest months (November and December) total monthly rainfall is decreasing while two wettest months (July and August) total monthly rainfall is increasing. Such pattern of rainfall changes affect the communities' water resources availability and increase the climatic uncertainties in the region.

People perceptions towards climate change in the region are consistent with what was observed. Most of the respondent experienced increased temperature, less snow fall and less water availability. People have noticed increase natural disasters frequency such as landslides and flooding, shift in monsoon rainfall, intense rainfall during monsoon, and prolonged drought events. This makes the community more vulnerable to climate change. People are aware of the changes and already experienced the problems but do not know the solutions.

This is a small case study that related people's perception on what physically measured in terms of climate. We find that the communities' perceptions are consistent with the measured climate change. The compounding impacts of climate change are already experienced and are expected to increase in future. The impacts are direct to local communities such as Khudi but mitigation measures are beyond their control. So it is recommended to develop and implement short to long term effective adaptation measures to minimize the risks associated with climate change. The policies should be formulated and implemented in way that it changes communities' challenges into opportunities.

\section{Acknowledgements}

Funding for this research was obtained as Research \& Action Grants for Disaster Risk Reduction (2007/2008) from ProVention Consortium, Switzerland; I would like to thank them. Dr. Keshav Pd Sharma (DHM) and Prof. Dr. Narendra Raj Khanal (Tribhuvan University) has guided me to carry out this research. I acknowledge them. I would like to thank my friends Yubraj Satyal, Raju Pokharel, Mausam Khanal, Jagdish Paudel and Baburam Lamichhane for their immense help and support. Thank you all.

Aseem Raj Sharma is a Ph.D. student in Environmental Science Program at Northern 
Hydrometeorology Group (NHG), Natural Resources and Environmental Studies Institute (NRESi), University of Northern British Columbia, Prince George, BC, Canada, V2N4Z9.

Corresponding address: nature.aseem@gmail.com

\section{Referances}

Adger, W. N. (2000). Social and Ecological Resilience: Are They Related? Progress in Human Geography, 24 (3), 347-364.

Adger, N., Huq, S., Brown, K., Conway, D., \& Hulme, M. (2003). Adaptation to climate change in the developing world.ProgressinDevelopmentStudies, 3(3), 179-195. doi:10.1191/1464993403pso6ooa

Bharati, L., Gurung, P., \& Jayakody, P. (2012). Hydrologic Characterization of the Koshi Basin and the Impact of Climate Change. Hydro Nepal: Journal of Water, Energy and Environment, (Special Issue on Proceedings of National Conference on Water, Food Security and Climate Change in Nepal), 18-22.

Baidya, S. K., Shrestha, M. L., \& Sheikh, M. M. (2008). Trends in daily climatic extremes of temperature and rainfall in Nepal. Journal of Hydrology and Meteorology, 5(1).

CBS. (2006). District Profile of Lamjung District. Statistical Section Office Gorkha, Central Bureau of Statistics, National Planning Commission Secretariat, Government of Nepal.

Gurung, P., Bharati, L., \& Karki, S. (2013). Application of the SWAT Model to assess climate change impacts on water balances and crop yields in the West Seti River Basin. In D. Kiniry, C. Smith, \& R. Srinivasan (Eds.), 2013 International SWAT Conference (pp. 175-191). Toulouse, France: Texas AgriLife Research, Texas A\&M University, USA.

Hua, O. (2009). The Himalayas - water storage under threat. (No. Sustainable Mountain Development
No. 56, ICIMOD, Winter 2009). Water Storage - A strategy for climate change adaptation in the Himalayas.

IPCC. (2007). Climate Change 2007: Impacts, Adaptation and Vulnerability. Contribution of Working Group II to the Fourth Assessment Report of the Intergovernmental Panel on Climate Change. (O. C. M.L. Parry, Ed.) 617-652.

IPCC. (2007). Climate Change 2007: Synthesis Report. Intergovernmental Panel for Climate Change.

IPCC. (2013). Climate Change 2013: The Physical Science Basics. Contibution of Working Group I to the Fifth Assessment Report of the Intergovernmental Panel on Cliamte Change. (T. F. Stocker, D. Qin, G.-K. Plattner, M. Tignor, S. K. Allen, J. Boschung, ... P. M. Midgley, Eds.). Cambridge, United Kingdom and New York, NY, USA: Cambridge University Press. United Kingdom and New York, NY, USA: Cambridge University Press. Retrieved from http://www. climatechange2013.org/images/report/WG1AR5_ TS_FINAL.pdf

Shrestha, A., Wake, C., Mayewski, P., \& Dibb, J. (1999). Maximume Temperature Trends in the Himalaya and its Vicinity:An Analysis Based on Temprature Records from Nepal for the Period 1971-94. Journal of Climate, 12 (9), 2775-2786.

Stocker, T. F., D. Qin, Plattner, G.-K., Alexander, L. V., Allen, S. K., Bindoff, N. L., ... Gregory, J. M. (2013). Technical summary. In T. F. Stocker, D. Qin, G.-K. Plattner, M. Tignor, S. K. Allen, J. Boschung, ... P. M. Midgley (Eds.), Climate Change 2013: The Physical Science Basis. Contribution of Working Group I to the Fifth Assessment Report of the Intergovernmental Panel on Climate Change. Cambridge, United

Weiss, N., \& Hassett, M. (1982). Introductory Statistics. Addison- Wesley Publishing Company, Inc. 